Diabetologia 11, 35-38 (1975)

(c) by Springer-Verlag 1975

\title{
Relationship between Changes of Serum Cholecystokinin-Pancreozymin and Serum Insulin after Different Stimuli*
}

\author{
J. A. Grayburn, R. F. Harvey, R. D. Jennings, L. Dowsett and M. Hartog \\ University Department of Medicine, and Dept. of Chemical Pathology, Bristol Royal Infirmary, Bristol, England \\ Received: May 29, 1974, and in revised form: August 19, 1974
}

\begin{abstract}
Summary. The relationship between changes of serum immuno-reactive cholecystokinin-pancreozymin (CCK-PZ) and serum immuno-reactive insulin has been studied after various stimuli. The oral administration of $5 \%$ glucose or magnesium sulphate and the intra-duodenal administration of olive oil were all followed by a rise of serum CCK-PZ. The serum insulin rose after $5 \%$ glucose and also showed a
\end{abstract}

small but insignificant rise with olive oil. There was, however, no change of serum insulin after the ingestion of magnesium sulphate suggesting that CCK-PZ in isolation does not stimulate insulin release.

Key words: Cholecystokinin-pancreozymin, insulin release, glucose, magnesium sulphate, olive oil.
A relationship between intestinal hormones and the function of the exocrine and endocrine pancreas was postulated early this century $[1,2]$. More recently, it has been established that oral glucose stimulates a greater release of insulin than the equivalent amount administered intravenously $[3,4,5,6]$. It has been suggested that cholecystokinin-pancreozymin (CCKPZ) plays a role in this gastro-intestinal stimulation of insulin release in man [7,8]. In addition impure CCK-PZ preparations have been shown to enhance insulin release from the isolated perfused rat pancreas $[9,10]$. Furthermore, in dogs and rabbits intravenous CCK-PZ releases insulin $[11,12,13]$. Others have suggested that in man intravenous CCK-PZ stimulates insulin secretion, but endogenous CCK-PZ has no effect [14]. In the present study we have investigated this possibility using a recently developed radioimmunoassay for CCK-PZ [15].

\section{Materials and Methods}

The subjects studied were healthy male and female volunteers aged between 22 and 32 . Three substances were tested:

1. $500 \mathrm{ml} 5 \%$ glucose, given by mouth ( 6 subjects)

2. $0.1 \mathrm{G} / \mathrm{kg}$ magnesium sulphate in $150 \mathrm{ml}$ water given by mouth ( 6 subjects)

3. $40 \mathrm{ml}$ olive oil (Boots), introduced into the duodenum via a Ryle's tube, the position of which was first confirmed by radiological screening and measurement of the $\mathrm{pH}$ of the aspirate ( 4 subjects).

* Based in part on a paper presented to the British Diabetic Association on September $21^{\text {st }} 1973$.
Blood was taken via an indwelling intravenous cannula from a forearm vein with subjects in the sitting position. Samples were taken fasting, at 5 min intervals after the administration of the test substance for 30 to $35 \mathrm{~min}$, and thereafter at 45,60 and $75 \mathrm{~min}$. Blood glucose (glucose oxidase method) [16], serum immunoreactive insulin [17] and CCK-PZ were measured on each sample.

The radioimmunoassay used to measure CCK-PZ levels has recently been described in detail [15]. When using the rabbit antiserum MS 6/72, as employed in these studies, the immunological crossreaction with structurally similar gastrointestinal hormones (e.g. gastrin) appears to be insignificant. Absolute values for the level of CCK-PZ in human serum cannot, however, be given at the present time, for three reasons. Firstly, human CCK-PZ may cross-react in the assay to a degree which differs from that of the porcine hormone used as standard and tracer. Secondly, no highly purified standard CCK-PZ preparation of known stability and biological potency is currently available for any species of CCK-PZ. The standard preparation used in the studies, although stable, contains less immunoreactivity than expected, and measured levels of CCK-PZ-like immunoreactivity will therefore require division by some common factor when a suitable standard preparation becomes available. Thirdly, the assay appears to be capable of measuring at least three cholecystokinins, of different molecular weight, but sharing a common C-terminal structure. It is not at present known which of these are present in serum, nor in what proportion, and their relative immunoreactivities and biological potencies are also unknown. 
Despite these reservations, the assay is capable of assessing and comparing the CCK-PZ release after different stimuli.

\section{Results}

(a) After the ingestion of $5 \%$ glucose (Fig. 1) the blood glucose rose from a mean of $71 \mathrm{mg} / 100 \mathrm{ml}$ to a peak of $122 \mathrm{mg} / 100 \mathrm{ml}$ at $30 \mathrm{~min}$, and this was accompanied by a rise of serum insulin. There was

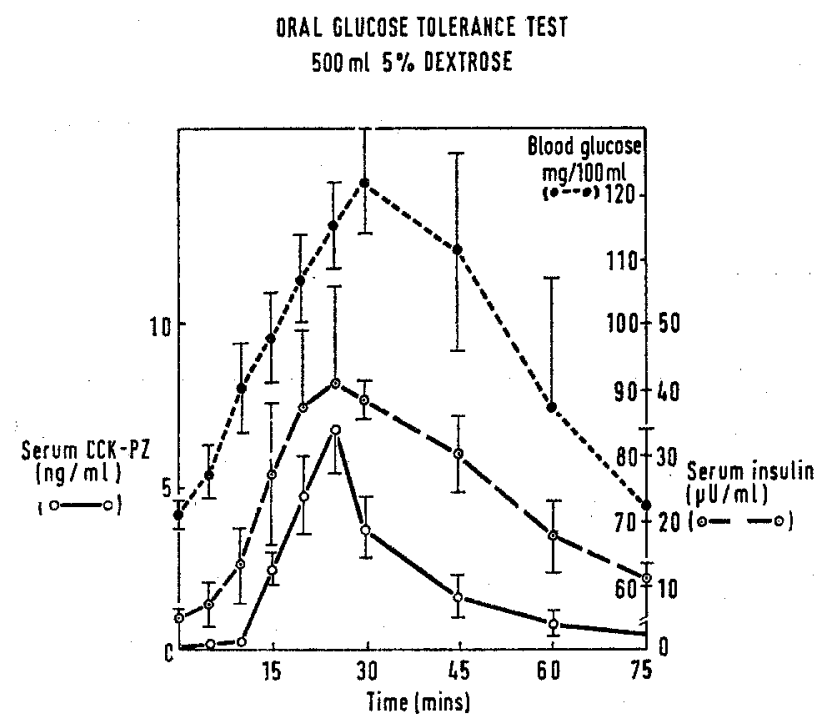

Fig. 1. Changes of serum CCK-PZ, insulin and blood glucose following ingestion of $500 \mathrm{ml}$ of $5 \%$ glucose (Mean $\pm \mathrm{SEM}$ )

\section{ORAL $\mathrm{MgSO}_{4}$ TEST $(0 \cdot 1 \mathrm{~g} / \mathrm{kg}) ;$ SERUM CCK-PZ AND INSULIN}

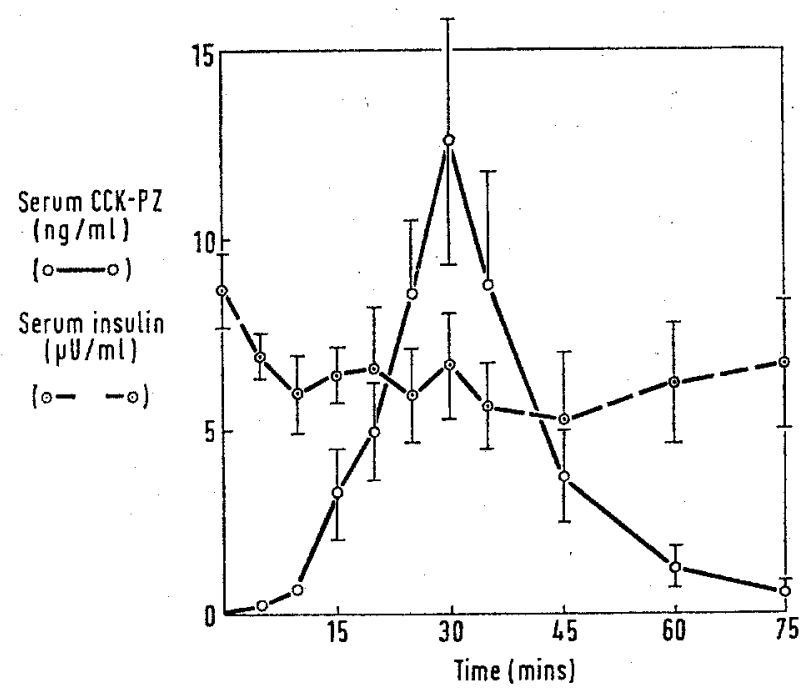

Fig. 2. Changes of serum CCK-PZ and insulin following magnesium sulphate $(0.1 \mathrm{G} / \mathrm{kg}$ ) ingestion (Mean \pm SEM) a rise of serum CCK-PZ which reached a peak level of $6.6 \mathrm{ng} / \mathrm{ml}$ at approximately the same time as the serum insulin.

(b) The ingestion of magnesium sulphate (Fig. 2) resulted in a rise of serum CCK-PZ which reached a peak of $12.7 \mathrm{ng} / \mathrm{ml}$ at $30 \mathrm{~min}$. There was no rise of serum insulin nor was there any fall in blood glucose.

(c) The intraduodenal instillation of olive oil (Fig. 3) produced a rise of serum CCK-PZ to a peak level

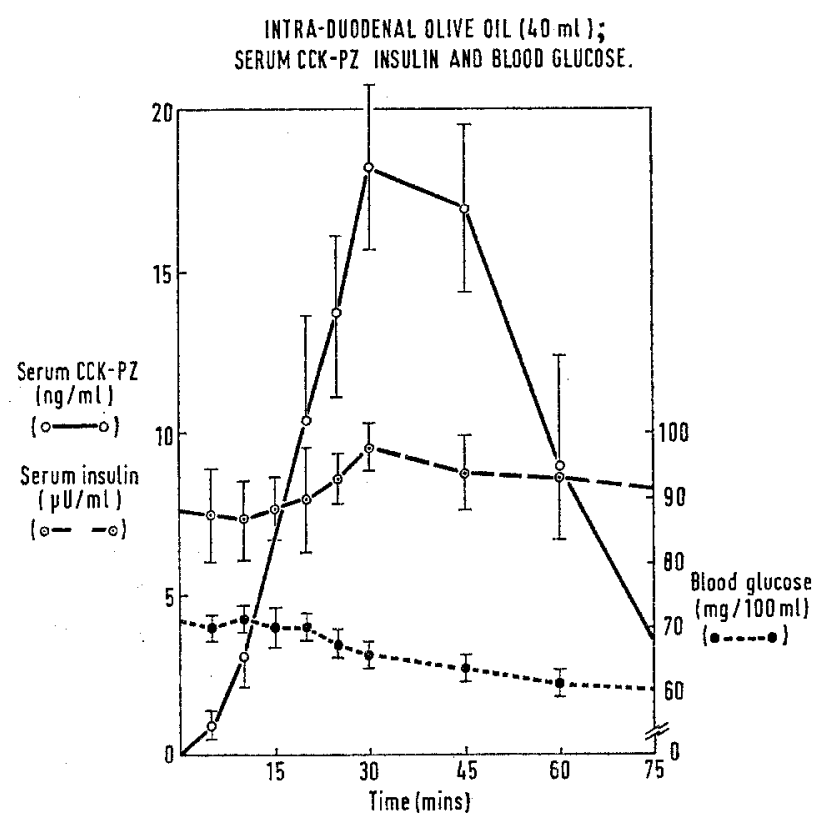

Fig. 3. Changes of serum CCK-PZ, insulin and blood glucose following $40 \mathrm{ml}$ intraduodenal olive oil (Mean \pm SEM)

of $18.3 \mathrm{ng} / \mathrm{ml}$. This response was more prolonged than after magnesium sulphate. There was a small but insignificant $(p<0.15)$ rise of serum insulin and a fall of blood glucose.

These results are summarised in Table 1.

\section{Discussion}

The results reported in this paper indicate that there is no consistent relationship between changes of the levels of serum immunoreactive CCK-PZ and insulin in man. Thus, the ingestion of magnesium sulphate, a potent CCK-PZ releasing agent [18], had no significant effect on the level of serum insulin. In contrast, previous studies have suggested that CCK-PZ does cause insulin release in man $[7,8]$. The majority of these studies, however, have involved investigating 
the effect of relatively impure preparations of CCK$\mathrm{PZ}$ on insulin release, and it seems probable that these preparations contained other active substances. In fact, whereas $50 \%$ and $10 \%$ pure preparations produced an elevation of serum insulin, highly purified preparations (99\% pure) of the intestinal hormone have been reported to cause no insulin release [19-21]. Recently it has been shown that intravenous injection of gastric inhibitory peptide (GIP) causes insulin release, and it may be that this substance, which is present in impure preparation of CCK-PZ, was responsible for the rise

Table 1. Mean fasting and mean peak values ${ }^{2}$ for each subject of serum immunoreactive CCK-PZ and insulin \pm S.E.M. after the administration of oral glucose and $\mathrm{MgSO}_{4}$ and intraduodenal olive oil

\begin{tabular}{|c|c|c|}
\hline & Insulin $(\mu \mathrm{u} / \mathrm{ml})$. & CCK-PZ (ng/ml.) \\
\hline & Fasting Peak & Fasting Peak \\
\hline $\begin{array}{l}\text { Glucose } \\
n=6\end{array}$ & $\begin{array}{c}5.5 \pm 1.1 \quad 44.8 \pm 14.7 \\
p<0.05\end{array}$ & $\begin{array}{c}0.03 \pm 0.02 \quad 6.6 \pm 1.3 \\
p<0.005\end{array}$ \\
\hline $\begin{array}{l}\mathrm{MgSO}_{4} \\
\mathrm{n}=6\end{array}$ & $\begin{array}{c}8.8 \pm 1.19 .4 \pm 1.6 \\
\text { N.S. }\end{array}$ & $\begin{array}{c}0.02 \pm 0.01 \quad 14.6 \pm 2.6 \\
p<0.001\end{array}$ \\
\hline $\begin{array}{l}\text { Olive oil } \\
\mathrm{n}=4\end{array}$ & $\begin{array}{c}7.7 \pm 1.2 \quad 10.6 \pm 1.3 \\
\text { N.S. }\end{array}$ & 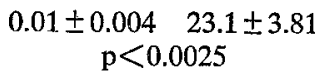 \\
\hline
\end{tabular}

${ }^{a}$ Mean of the individual peak values for each subject

in serum insulin seen after injection of impure preparations of CCK-PZ [21]. The rise of serum CCK-PZ found after glucose was greater than we had anticipated, as carbohydrates appear generally to have little effect on gallbladder contraction [22] and pancreatic enzyme secretion [23]. This release of CCK$\mathrm{PZ}$ by $5 \%$ glucose solutions may to some extent be non-specific, as release of CCK-PZ appears to be similarly stimulated by both water and normal saline $[24,25,26]$.

Despite the large increase of serum CCK-PZ following intraduodenal olive oil, there was only a slight rise of serum insulin, as has previously been shown with corn oil. This small insulin rise might have resulted from the direct effect of absorbed fatty acids on the pancreatic B cells [27].

These findings do not necessarily mean that CCK$\mathrm{PZ}$ plays no physiological role in insulin release, as it is possible that it could have an effect on the B cells which is synergistic either with other gastrointestinal hormones, or with a high or rising blood glucose concentration. It does, however, seem unlikely that in man the insulin-releasing effect of CCK-PZ (if any) is as powerful as previous studies have suggested. Fur- ther investigations using pure CCK-PZ preparations are required to resolve these questions.

Acknowledgments: We thank Professor V. Mutt, Karolinska Institute, Stockholm, for gifts of highly purified CCKPZ, Mr. G. James for the illustrations, Mr. J. Goodings for assistance with the serum insulin assays and Professor A. E. Read for continuing encouragement and support. This work was supported in part by the Medical Research Council.

\section{References}

1. Bayliss, W. M., Starling, E. H.: Mechanism of pancreatic secretion. J. Physiol. (Lond.) 28, 325-353 (1902)

2. Dale, H.: On the islets Langerhans in the pancreas. Phil. Trans. 197, B 25-46 (1905)

3. McIntyre, N., Holdsworth, C. D., Turner, D. S.: Intestinal factors in the control of insulin secretion. J. clin. Endocr. 25, 1317-1324 (1965)

4. Scow, R. O., Cornfield, J.: Quantitative relations between the oral and intravenous glucose tolerance curves. Amer. J. Physiol. 179, 435-438 (1954)

5. Conard, V., Franckson, R. I., Bastenie, P. A., Kestens, I. C., Kovacs, L.: Etudes critiques du triangle d'hyperglycémie intraveineux chez l'homme normal et determination d'un coefficient d'assimulation glucidique. Arch. Int. Pharmacodyn. 93 , 277-284 (1953)

6. Elrick, H., Stimmler, C., Hlad, C. J., Jr., Arai, Y.: Plasma insulin response to oral intravenous glucose administration. J. clin. Endocr. 24, 1076-1082 (1964)

7. Schröder, L. E., Raptis, S., Faulhaber, J. D., Pfeiffer, E. F.: Die Wirkung von Pankreozymin auf Blutzucker, immunologisch meßbarem Insulin, freien Fettsäuren und Glycerin beim Menschen. In: Symp. Dtsch. Ges. Endokrinologie, Heidelberg, 7-9 März 1968 S. 170-171 Heidelberg: Springer-Verlag (1969)

8. Dupré, J., Curtis, J. D., Waddell, R. W., Beck, J. C.: Regulation of pancreatic endocrine function by gastrointestinal hormones. Proc. roy. Soc. Med. 8, 815-816 (1968)

9. Fußgänger, R. D., Straub, K., Goberna, R., Jaros, P., Schröder, K. G., Raptis, S., Pfeiffer, E. F.: Primary secretion of insulin and secondary release of glucagon from isolated perfused rat pancreas following stimulation with pancreozymin. Horm. Metab. Res. 1, 224-227 (1969)

10. Hinz, M. N., Katsilambros, N., Schweitzer, B., Raptis, S., Pfeiffer, E.F.: The role of the exocrine pancreas in the stimulation of insulin secretion by intestinal hormones. 1. The effect of pancreozymin, secretin, gastrin-pentapeptide and of glucagon upon insulin secretion of isolated islets of rat pancreas. Diabetologia 7, 1-5 (1971)

11. Unger, R. H., Ketterer, H., Dupré, J., Eisentraut, A.: The effects of secretin, pancreozymin and gastrin on insulin and glucagon secretion in anesthetized dogs. J. clin. Invest. 46, 630-645 (1967)

1.2. Meade, R. C., Kneubuhler, H. A., Schulte, W. J., Barboriak, J. J.: Stimulation of insulin secretion by pancreozymin. Diabetes 16, 141-144 (1967)

13. Lucke, C., Höffken, B., Mitzkat, H. J., Trautschold, I.: Effect of 2-deoxy-D-glucose and mannoheptulose on the insulin response to pancreozymin in rabbits. Horm. Metab. Res. 6, 21-25 (1974)

14. Mahler, R. J., Weisberg, H.: Failure of endogenous stimulation of secretin and pancreozymin release to influence serum insulin. Lancet $1968 \mathrm{I}, 448-451$ 
15. Harvey, R. F., Dowsett, Lynda, Hartog, M., Read, A. E.: Radioimmunoassay of cholecystokinin-pancreozymin. Gut 15, 690-699 (1974)

16. Pennock, C. A., Murphy, D., Sellers, J., Longdon, K. J.: A comparison of auto-analyser methods for the estimation of glucose in blood. Clin. chim. Acta 48, 193-201 (1973)

17. Keane, P. M., Pearson, J., Walker, W. H. C.: Dextrancoated charcoal immunoassay of insulin. Diabetologia 4, 339-344 (1968)

18. Harvey, R. F., Read, A. E.: Saline purgatives act by releasing cholecystokinin. Lancet $1973 \mathrm{I}, 185-187$.

19. Hedner, P., Persson, G., Ursing, D.: Failure of intravenous cholecystokinin to elicit insulin release in man. Acta Endocr. Suppl. 177, 327 (Abst.) (1973)

20. Rabinowitch, A., Dupré, J.: Insulinotropic and glucagonotropic activities in crude preparations of cholecystokininpancreozymin. Clin. Res. 20, 945 (1972)

21. Rabinowitch, A., Dupré, J.: Effects of the gastric inhibitory polypeptide present in impure pancreozymin-cholecystokinin on plasma insulin and glucagon in the rat. Endocrinology 94, 1139-1144 (1974)

22. Ivy, A. C.: The physiology of the gallbladder. Physiol. Rev. 14, $1-102$ (1934)
23. Wang, C. C., Grossman, M. I.: Physiological determination of release of secretin and pancreozymin from intestine of dogs with transplanted pancreas. Amer. J. Physiol. 164, 527-545 (1951)

24. Harper, A. A., Vass, C. C. N.: The control of the external secretion of the pancreas in cats. J. Physiol. (Lond.) 99, 415-435 (1941)

25. Bergström, K., Lundh, G.: Determination of trypsin in duodenal fluid as a test of pancreatic function. A methodological note. Scand. J. Gastroent. 5, 533-536 (1970)

26. Lurie, B., Novis, B. H., Brom, B., Bank, S., Marks, I. N.: Pancreatic exocrine responses to test meals of varying composition in man. Amer. J. dig. Dis. 18, 847-850 (1973)

27. Pi Sunyer, X. F., Hashim, S. A., Van Itallie, T. B.: Insulin and ketone responses to ingestion of medium and longchain triglycerides in man. Diabetes 18, 96-100 (1969)

R. F. Harvey, M. D.

Univ. of Bristol

Dept. of Medicine

Bristol Royal Infirmary

Bristol BS2 8HW

England 